COMMENT

DOI: $10.1057 /$ s41599-017-0010-7

\title{
Countering racism in counter-terrorism and surveillance discourse
}

Katy $\operatorname{Sian}^{1}$

\begin{abstract}
The war on terror prompted a surge of counter-terror measures across Western democracies in the campaign to contain extremism. The effects of this increased securitization has had major consequences for Muslim and racialized populations more generally, who have found themselves caught up in state surveillance and counter-terror operations. Loose and vague definitions of extremism have meant that the category of 'terror suspect' continues to be underpinned by Orientalist, racist, and Islamophobic articulations. This paper offers an introduction to an article collection that seeks to critically address the historical shifts and contemporary developments in counter-terrorism discourse, and their impact upon racial groups in national and international contexts.
\end{abstract}

\footnotetext{
${ }^{1}$ Department of Sociology, University of York, Heslington, York, YO10 5DD, UK. Correspondence and requests for materials should be addressed to K.S. (email: katy.sian@york.ac.uk)
} 


\section{Introduction}

he war on terror prompted a surge of counter-terror measures across Western democracies in the campaign to contain extremism. The effects of this increased securitization has had major consequences for Muslim and racialized populations more generally, who have found themselves caught up in the murky web of state surveillance and counter-terror operations (Ahmad, 2002, pp 101-108). Loose and vague definitions of extremism have meant that the very category of 'terror suspect' continues to be underpinned by Orientalist, racist, and Islamophobic articulations (Sian, 2015, pp 190-201). From the implementation of the British government's Prevent policy to the authorization of the USA Patriot Act, a shadowy condition has emerged in which communities of color have been governed and regulated through systematic practices of racism under the guise of national security (Bayoumi, 2006, pp 267-268). On the ground this has produced the sophistication of racial profiling methods such as the spying on Muslims in public sector organizations, No Fly Lists, body scanners at airports, and advanced biometrics producing masses and masses of data on citizens (Lustick, 2006, p 32; Guzik, 2009, p 3; Amoore, 2009, p 18; Dhamoon, 2013, pp 7-10; Florence, 2006, pp 2148-2150). The intensification of surveillance has also further strengthened unjust practices of torture, rendition, extradition, and mass incarceration.

The implementation of counter-terror measures in western nations as a way to manage 'threatening' racial bodies is not a new phenomenon. From Hoovers Counter Intelligence Programme (COINTELPRO), developed to shut down and eliminate groups including civil rights organizations, the black panther party, and advocates of American Indian sovereignty; to the extradition of aborigines; the monitoring of refugees and migrants through strict border control; and regular stops and searches of black youth, state surveillance directed towards communities of color has had a long seated history. The war on terror can therefore be seen as the catalyst that propelled and advanced the reach of security.

\section{Article collection}

This article collection comprises a range of papers (including, Lentin, 2017; Qureshi, 2017; Eski and Eski, 2017; Patel, 2017) that seek to critically address the historical shifts and contemporary developments in counter-terrorism discourse, and their impact upon racial groups in national and international contexts. In an age when the risk of terrorism and political violence is perceived to be severe by western nations, this collection speaks seriously to the contemporary climate as a way to question the effectiveness of current counter-terrorism programs. It examines the consequences of surveillance on ethnically marked populations and draws out the conceptual interconnections between the security apparatus and the exercise of racialized governmentality (Hesse and Sayyid 2006, p 21).

The contributions to this collection offer some key insights into the way in which counter-terrorism measures in the contemporary context have been structured by the logics of racism and Islamophobia. The prevent policy, which was officially introduced in the UK in 2006 as part of the governments broader post 9/11 counter-terrorism framework (CONTEST) is of particular significance. Demonstrating the ways in which largely Muslim populations have been racialized through a language of terror and extremism, the various contributions examine the complexities around the construction of the Muslim 'threat', which has been increasingly deployed as a key category to legitimize the expansion of draconian measures. Under the banners of security and safeguarding, the perpetual moral panic around 'suspect' communities continues to animate the witch-hunt against particular ethnically marked populations (Bayoumi, 2006, pp 267-269). However, as many of the papers in this collection point out, the systematic targeting of brown bodies not only strengthens Orientalist representations around 'otherness,' but it also reinforces racial hierarchies through an attempt to domesticate specific groups and communities.

This collection explores the conceptual and empirical dimensions of surveillance discourse and its relationship to the production of racism and Islamophobia. That is, through an examination of the targeting of communities of color, we are able to unravel the politics of state racism and more specifically the practice of Western governments. As such, the thread that brings this diverse set of papers together is a critique of structural power through an analytical engagement with critical race theory and postcolonial studies. By framing the debate through these approaches the collection is able to situate counter-terrorism discourse within the broader political context. With insights from academics, researchers and practitioners, this article series considers a range of different perspectives and will be of particular significance for those working in sociology, criminology, and critical terrorism studies, as well as policy makers and activists developing nuanced responses and strategies at the ground level. Moving beyond tedious, predictable and positivist explanations of terrorism, which have typically centered upon religion and culture, this collection seeks to shift the debate towards an understanding of counter-terrorism that focuses its attention upon the conceptual workings of racism, Islamophobia and the politics of inclusion and exclusion.

The embeddedness of counter-terrorism policies as part of the wider security structure has had the effect of normalizing Islamophobia in all aspects of public life by continuing to restrict Muslim agency (Sayyid, 2010, pp 5-18). These contemporary performances of state surveillance cannot be disentangled from historical manifestations of Western practice. This collection suggests that current patterns must be understood as the continuation of a long history that has been consistently premised upon the marginalization of racial bodies in a bid to maintain Western hegemony (ibid). In this on-going tension, the collection sheds light on the consequences of those who actively challenge the disproportionate use of state power. Through such accounts we can see the workings of the structural mechanisms that have been activated to suppress legitimate voices seeking to critique policy and practice. Raising important questions about the contested nature of citizenship and democracy, we are able to make sense of the ways in which particular regimes have used their stealth and strength to gather intelligence and intimidate those involved in dissent at the local and global level.

As the papers in this collection carefully document, counterterrorism measures including the Prevent program, 'torture flights,' and questionable policing tactics bring to the fore a number of important considerations around human rights abuses, state complicity, the use of force and the value of civil liberties. That is, through the expansion of security we have witnessed the routinization of Islamophobia, the curtailment of dissent, and the closing down of Muslim voices, all of which work to undermine the very idea of liberal democracy. A democracy that seeks to limit spaces for legitimate debate will prove largely ineffective, and as the various contributions demonstrate, increased securitization continues to pose major challenges for Muslim and non-Muslim communities.

Sayyid (2015) rightly argues that "de-radicalization programs tend to gloss over the systematic manner in which Western powers have been complicit in blocking and undermining the political expression of Muslims" (Sayyid, 2015). As such, a key outcome of the application of narrow, reductive and Orientalist 
frameworks to complex questions of counter-terrorism has been the intensification of institutionalized racism and Islamophobia across all aspects of society. Responding to these issues the range of textured critiques that feature in this collection offer an alternative platform for wider debate and discussion to take place. This collection therefore encourages readers to critically engage with understandings of counter-terrorism that move beyond positivist frameworks of de-radicalization and/or crude forms of assimilation. By developing a particular focus on the structural dimensions of power that bind together counter-terrorism, surveillance and articulations of racism/Islamophobia, the contributions urge a radical rethinking of state policies and practice. What is made clear throughout-both historically and presently, as well as conceptually and empirically-is that the very premise of counter-terrorism discourse (whether through policing practice, surveillance measures, and so on) facilitates, empowers, and legitimizes the exclusion of racial bodies.

Received: 21 September 2017 Accepted: 21 September 2017

Published online: 24 October 2017

\section{References}

Ahmad M (2002) Homeland insecurities: racial violence the day after september 11. Social Text 20(3):101-115

Amoore L (2009) Lines of sight: on the visualization of unknown futures. Citizensh Stud 13(1):17-30

Bayoumi M (2006) Racing religion. Centen Rev 6(2):267-293

Dhamoon R (2013) Exclusion and regulated inclusion. Sikh Form 9(1):7-28

Eski S, Eski Y (2017) Dutch tolerance of torture? CIA extraordinary rendition flights in the Netherlands. Palgrave Commun 3, Article number: 17084. https://doi.org/10.1057/palcomms.2017.84

Florence J (2006) Making the no fly list fly: a due process model for terrorist watchlists. Yale Law J 115(8):2148-2181

Guzik K (2009) Discrimination by design: predictive data mining as security practice in the United States war on terrorism. Surveill Soc 7(1):1-17

Hesse B, Sayyid S (2006) The postcolonial political and the immigrant imaginary. In: Ali N, Kalra V, Sayyid S (eds) A postcolonial people: South Asians in Britain. Hurst and Company, London, pp 13-33
Lentin R (2017) Race and surveillance in the settler colony: the case of Israeli rule over Palestine. Palgrave Commun 3, Article number: 17056. https://doi.org/ 10.1057/palcomms.2017.56

Lustick I (2006) Trapped in the war on terror. University of Pennsylvania Press, Philadelphia

Patel TG (2017) It's not about security, it's about racism: counter-terror strategies, civilizing processes and the post-race fiction. Palgrave Commun 3, Article number: 17031. https://doi.org/10.1057/palcomms.2017.31

Qureshi A (2017) Fight the power: how CAGE resists from within a "suspect community". Palgrave Commun 3, Article number: 17090. https://doi.org/ 10.1057/palcomms.2017.90

Sayyid S (2015) Attacking all of humanity? Daily Sabah, 30 Nov 2015

Sayyid S (2010) Out of the Devil's dictionary. In: Sayyid S, Vakil A (eds) Thinking through Islamophobia. Hurst and Company, London, pp 5-18

Sian K (2015) Spies, surveillance and stakeouts: monitoring muslim moves in british state schools. Race Ethn Educ 18(2):183-201

\section{Additional information}

Competing interests: The author declares no competing financial interests.

Reprints and permission information is available online at http://www.nature.com/ reprints

Publisher's note: Springer Nature remains neutral with regard to jurisdictional claims in published maps and institutional affiliations.

\footnotetext{
(c) ()

Open Access This article is licensed under a Creative Commons Attribution 4.0 International License, which permits use, sharing, adaptation, distribution and reproduction in any medium or format, as long as you give appropriate credit to the original author(s) and the source, provide a link to the Creative Commons license, and indicate if changes were made. The images or other third party material in this article are included in the article's Creative Commons license, unless indicated otherwise in a credit line to the material. If material is not included in the article's Creative Commons license and your intended use is not permitted by statutory regulation or exceeds the permitted use, you will need to obtain permission directly from the copyright holder. To view a copy of this license, visit http://creativecommons.org/ licenses/by/4.0/.
}

(C) The Author(s) 2017 